\title{
AKT3 Gene Amplification
}

National Cancer Institute

\section{Source}

National Cancer Institute. AKT3 Gene Amplification. NCI Thesaurus. Code C132895.

A molecular genetic abnormality indicating the presence of multiple copies of the AKT3 gene. 